\title{
PReS-FINAL-2050: Determination of the concentration of methotrexate in the blood serum of patients with JIA
}

\author{
F Rokhlina*, G Novik \\ From 20th Pediatric Rheumatology European Society (PReS) Congress \\ Ljubljana, Slovenia. 25-29 September 2013
}

\begin{abstract}
Introduction
Juvenile idiopathic arthritis (JIA) is the most common rheumatic disease among children. Among patients with JIA often meets resistance to the therapy of various drugs, including nonsteroidal anti-inflammatory drugs (NSAIDs), intraarticular injections and physiotherapy. For the treatment of JIA is used several groups of drugs: NSAIDs, corticosteroids (CS), immunosuppressive drugs and biologically active substances obtained genno-ingenerian. Application NSAIDs and GS have anaesthetic and anti-inflammatory effects, but do not contribute to the prevention of destruction of the joints and disability of patients. The « gold standard $\gg$ in the treatment of JIA can be considered methotrexate (MTX) - cytostatic drug groups of antimetabolites, antagonists folic acid. MTX has expressed immunosupression action, even at relatively low doses, with no noticeable hematologic toxicity. Despite this, when taking methotrexate recommended clinical and laboratory monitoring is needed to prevent side effects. According to various authors, about $70 \%$ of patients receiving MTX consists in the remission of the disease.
\end{abstract}

\section{Objectives}

The aim of our study is to define the efficient MTX concentration in the blood serum of patients with JIA.

\section{Methods}

All children included in the study received basic therapy with methotrexate dose of $15 \mathrm{mg} / \mathrm{m} 2$ over 3 months and more. All the children were conducted routine methods of research, objective examination and determined the MTX concentration in the serum.

SPbGPMU, St. Petersburg, Russian Federation

\section{Results}

We examined 103 child patients with JIA, among which - $65(63,11 \%)$ girls and $38(36,89 \%)$ boys with various forms of juvenile idiopathic arthritis. Children with polyarthritis - 46 (44,66\%), with olygoarthritis JIA - 25 children $(24,27 \%)$, systemic type of arthritis diagnosed with 14 children $(13,59 \%)$, enthesitassociated arthritis met in 18 patients $(17,48 \%)$.

35 patients (34\%) to the treatment with MTX added biologically active therapy, 11 patients $(10,68 \%)$ receive in addition to the MTX therapy sulfasalazine, 24 child $(23,3 \%)$ - cyclosporine A, 37 children $(35,92 \%)$ being prednisone or methylprednisone (in tablets or in the form of a pulse therapy). Noteworthy is that $46(44,66 \%)$ patients have the positive effects of MTX monotherapy, does not require the appointment of additional drugs.

\section{Conclusion}

According to the information we received data MTX concentration in the serum was in the range of 0.76 $\mathrm{mmol} / \mathrm{ll} A$ to $3,96 \mathrm{mmol} / \mathrm{L}$. Significant differences depending on the activity of the disease, type of arthritis, treatment duration MTX were received. Thus the definition of MTX concentration in the blood serum of patients with JIA not let to forecast the efficiency of the therapy.

MTX has a good safety profile. To reduce the risk of side effects, appoint folic acid at a dose of 1-5 mg) in the days when MTX is not used, because while receiving folic acid may reduce the effectiveness of MTX. An important feature of the use of this drug is to use 1 time a week.

The use of cytostatic therapy (MTX) is the drug of choice in all countries for the treatment of various forms of JIA and is the gold standard. 


\section{Disclosure of interest}

None declared.

Published: 5 December 2013

doi:10.1186/1546-0096-11-S2-P63

Cite this article as: Rokhlina and Novik: PReS-FINAL-2050: Determination

of the concentration of methotrexate in the blood serum of patients with JIA. Pediatric Rheumatology 2013 11(Suppl 2):P63.

Submit your next manuscript to BioMed Central and take full advantage of:

- Convenient online submission

- Thorough peer review

- No space constraints or color figure charges

- Immediate publication on acceptance

- Inclusion in PubMed, CAS, Scopus and Google Scholar

- Research which is freely available for redistribution 